\title{
Spejlets gåde
}

\section{Strukturelle og filosofiske aspekter i Augustins Bekendelser}

\author{
Lektor, ph.d., dr.theol. Lars Albinus
}

\begin{abstract}
In this article the point of departure for presenting a hermeneutic reading of Augustine's Confessiones is taken in St. Paul 1 Cor. 13:12 where Paul speaks of our being earthly conditioned to see everything in a mirror as if in a riddle until we stand face to face with our creator. In a selective reading of Confessiones, I argue that the book is structured in a two-layered manner in which the relationship between Augustine and his earthly parents is transposed to a relationship between these relatives, on the one hand, and their heavenly parents in God and his church, on the other. I further argue that Augustine's individual life story in a similar vein gains its fulfilment in the creation and consummation of the world. Thus, in the concluding exegesis of the introducing verses of Genesis, in which God's concreatio of time and matter mirrors human existence, Augustine unfolds the prospect of a totality only to be grasped face to face with the creator, that is, in the eschatological revelation of the love of God.
\end{abstract}

Key words: Augustine - Confessiones - mirror as metaphor - selfhood Kierkegaard - hermeneutic understanding - nature of love - the church as heavenly mother - personal life history - cosmology.

\section{Indledning}

Der er sagt og skrevet meget om Augustin (354-430) og ikke mindst om hans berømte skrift Confessiones (Bekendelser). ${ }^{1}$ Værket opfinder ikke 'bekendelsen' som litterær genre, men udnytter den på en unik måde takket være det samvirke af lidenskab og stil, der gør "hjertets uro" (inquietum est cor nostrum, 1.1) genkendelig for læseren. Hermeneutikkens idé om, at forståelsen af fortidige tekster følger af fortroligheden med deres horisont, er ikke svær at tilslutte sig her, hvis

1. Artiklen igennem benyttes Torben Damsholts oversættelse, Augustins Bekendelser (København: Sankt Ansgars Forlag 1998). Desuden henvises til den latinske tekst Confessionum libri tredecium i Patrologia latina vol 32, red., J.P. Migne (Turnhaut: Brepols 1969-1987). 
man ellers vover at tage skridtet ind i den på én gang fremmedartede og sært genkendelige verden, Bekendelser udfolder.

Artiklens hovedformål er at genfremstille denne verden med henblik på en indre sammenhæng mellem den personlige livshistorie og verdens skabelse, særligt hvad angår den tematiske forskydning fra menneskets kødelige eksistens til en himmelsk mod-eksistens. Udgangspunktet tages i den spejlmetafor for menneskets forhold til sig selv og Gud, som Augustin overtager fra Paulus, og hvortil jeg knytter en forbindelse til tanker hos Kierkegaard. Dermed træder jeg ud af en rent augustinsk horisont, men fastholder dog de aspekter, hvormed den åbner sig i forhold til vores egen. Selvom Augustins forhold til kristendommen næppe kan kaldes eksistentiel i nogen kierkegaardsk forstand, er det ikke desto mindre en af artiklens målsætninger at påvise oplagte ligheder mellem de to former for religiøs selv-refleksion.

Min læsning af Augustins tekst ligger hermeneutisk set i forlængelse af Paul Ricoeurs overvejelser over fortolkningens dialektiske forhold mellem en forstående og en forklarende indfaldsvinkel ${ }^{2}$. I nærværende artikel omsættes disse overvejelser konkret i forsøget på at åbne Bekendelsers verden i lyset af tekstens semantisk og narrativt strukturerede virkemidler. Jeg vil stille skarpt på bestemte betydningsrelationer, som jeg finder afgørende for arkitekturen i tekstens troshorisont.

\section{Spejlets gåde hos Paulus}

Augustin henviser flere gange i Bekendelser $(10,5 ; 12,13)$ til Paulus (1 Kor 13,12), der stiller en eskatologisk erkendelse i udsigt m.h.t. den guddommelige kærligheds uforgængelighed. Det er ikke ganske klart, om kærligheden blot er genstand for erkendelsen, eller om den tillige er erkendelsens subjekt. Man kunne måske sige, at den udgør den fuldkommenhed, der opløser det stykkevise ved den menneskelige erkendelse. Paulus skriver: "Nu ser vi jo i et spejl, i en gåde, men da skal vi se ansigt til ansigt; nu kender jeg stykkevis, man da skal jeg kende fuldt ud, ligesom jeg jo selv er kendt fuldt ud." Spejlmetaforen indgår selv i et spejlkabinet af intertekstuelle referencer ${ }^{3}$ og udgør således også en væsentlig referenceramme for Augustins Bekendelser.

2. Se Ricoeur, "Qu'est-ce qu'un texte? Expliquer et comprendre", Hermeneutik und Dialektik. Festschrift für H.G. Gadamer, II (Tübingen: Mohr/Siebeck 1970), 181-200.

3. Paulus refererer f.eks. til 4 Mos 12,8, hvor Herren om Moses siger, at "med ham taler jeg ansigt til ansigt, ligefremt og ikke i gåder, han får Herrens skikkelse at se"; endvidere findes parallel-udsagn hos Paulus selv i 1 Kor 8,3; 2 Kor 3,18 samt i Matt 5,8; Joh 3,2; Joh 10,14 og Åb 22,4. 
At se i et spejl er jo at se sig selv. I sidste ende er det os selv, der er gåden. Derfor afslører spejlet ingenting, det konfronterer os med os selv, med det forhold til os selv, som er selve spejlingen. Men hvad får os til at se i spejlet, hvad får os til at se os selv som os selv, hvis der ikke også er noget, ved hvilket vi adskiller os fra os selv, noget som gør, at vi bliver til et spørgsmål for os selv? For Paulus som for Augustin er mennesket allerede set af Gud, før det ser sig selv. Skabt af Gud i Guds billede ser mennesket sig selv, men det betyder ikke, at det af egen kraft er i stand til at se andet end sig selv. Selv $i$ Gud ser det kun sig selv, hvis det ikke samtidig ved Gud foranlediges til at se ud over sig selv, stykkevis og ikke i skuen, men i tro.

Kan mennesket da i sidste ende se ud over sig selv? Svaret får vi ikke, heller ikke hos Augustin, men det betyder ikke, at selvets gåde, som i en vis forstand forbliver en gåde, blot fremstår som en selvcentreret navlebeskuelse i Bekendelser, snarere tværtimod. Som hos AntiClimacus, hvor selvforholdets fortvivlelse først lader sig helbrede ved at grunde gennemsigtigt i den magt, som har sat det, ${ }^{4}$ finder Augustins urolige hjerte (1.1) først hvile ved at se sig selv som skabt af Gud (13.35). Det er gennem dette syn på sig selv, at han kan istemme Paulus' udsagn, om at vi engang skal se, ikke stykkevis men fuldkomment - ansigt til ansigt med skaberen. Men hvad betyder dette? At vi endelig skal se mere end os selv, at vi skal skue kærligheden? Er gåden et løfte eller et håb? Gåden forbliver på endelighedens betingelser en gåde. Men deri overskrider den allerede sig selv. Guds ord er - som det spejl i hvilket mennesket ser sig selv i forhold til noget andet pant på uendeligheden.

\section{På vej mod omvendelsen}

Det spørgsmål, der fra begyndelsen af melder sig for Augustin, er hvorledes en henvendelse til Gud overhovedet kommer i stand. Problemet er, at Augustin, når han påkalder Gud, kalder ind i sig selv (1.2) og derfor må spørge: "Hvor er det sted i mig, hvor min Gud kan komme ind?"5 Spørgsmålet afføder blot et nyt, nemlig: "Kan himlen og jorden, som du skabte, og i hvilke du har skabt mig, rumme dig?"' Svaret må vente. Kun gradvist gennem de første 9 bøger lader Augustin den erkendelse tone frem, at det er selve spørgsmålene, der er forkert stillede, affødte som de er af en manikæisk dualisme.

4. Jf. Kierkegard, SKS 11, Sygdommen til Døden (København: Gads Forlag 2006), A.A., 130 .

5. Et quis locus est in me quo veniat in me Deus meus?

6. An vero calum et terra qua fecisti, et in quibus me fecisti, capiunt te? 
Den materialistiske opfattelse af altings todelte natur, lysets og mørkets kræfter, som Augustin har udvundet af denne lære, har i hans retrospektive selvforstålse grundlagt hele perspektivet for den måde, han i sin ungdoms vildfarelse spurgte ind til Guds natur på. I kapitel 4 besvarer han spørgsmålet med en lovprisning af Gud, der bl.a. kaldes "den uforanderlige som forandrer alt, den aldrig nye og aldrig gamle, som fornyer alt" - og, hvad der nok så interessant, som "den mest skjulte og mest nærværende" (secretissime et prasentissime, 1.4). Spørgsmålet synes stillet på ontologiens præmisser, men 'svaret' gives på bekendelsens. Gud er uforanderlig, skabningen er foranderlig og som sådan alene til ved Gud (1.2), som fornyer alt (1.4). For så vidt som Gud både er den mest skjulte og den mest nærværende, ${ }^{7}$ forbliver Gud en gåde, men en gåde, der viser sig som det mest nærværende for tanken og for hjertet, med andre ord: Gud er den gåde, der trænger sig på i menneskets forhold til sin egen væren. Kun i bekendelsen til Gud kan Augustins liv fremstå med en indre sammenhæng. Og sammenhængen knyttes allerede på dette sted til verdens skabelse, som udgør en implicit baggrund for hans spørgen (Gen 1-2,4). I 'genfortællingen' af sine egne ungdommelige betragtninger skrider Augustin nemlig direkte fra spørgsmålet om, hvorvidt han selv kunne rumme Gud, til spørgsmålet om, hvorvidt den himmel og jord, som han selv var blevet til ved, kunne rumme Gud.

Augustin vender flere gange tilbage til spørgsmålet om, hvorledes det overhovedet er muligt at begribe skaberen på den skabte verdens betingelser. Det går op for ham, at en manikæisk, materialistisk forståelseshorisont i sin tid fik ham til at stille forkerte spørgsmål. Dels forekom det ham allerede i ungdomsårene pinligt, at han ikke var i stand til at tænke nogen "substans anderledes end det man plejer at se med egne øjne" (aliquid substantia nisi tale non poteram, quale per hos oculos videri solet, 7.1), dels endte han med at indse det absurde i at forestille sig Gud som noget legemligt. Konsekvensen ville jo være, at en elefant var mere 'opfyldt' (plena) af Gud end en spurv (7.2). Samtidig antydes retrospektivt en vej ud af kniben: "Jeg var ikke opmærksom på, at selve den opmærksomhed, hvormed jeg forestillede mig disse former, ikke var som dem" (7.2). ${ }^{8}$ Augustin erkender med andre ord, at det ikke er en 'objektiv' materialitet, men selve synsvinklen, der er afgørende. At se en sammenhæng i det usammenhængen-

7. Dette skal næppe forstås som en gradbøjning, eftersom Gud også kaldes den "mest almægtige" (omnipotentissime), hvilket er en grammatisk umulighed. Superlativerne skal derfor snarere forstås således, at Gud er almægtighed som sådan, og ligeledes 'det skjulte' og 'det nærværende' som sådan.

8. Nec videbam hanc camdem intentionem, qua illas opsas imagines formabam, non esse tale aliquid. 
de, eller at se det uforanderlige i det foranderlige (7.17), er at se livet under evighedens synsvinkel, sub specie aeternitatis. ${ }^{9}$ Han bliver efterhånden klar over, at synsfeltet må skifte retning. Den ydre verden kan ikke løse værens gåde for ham; svaret må, hvis det findes, søges i ham selv. Men dette øger blot hjertets uro. Mere hvileløs end nogen sinde prøver han at forstå, hvad han ikke kan forstå, fordi det allerede ligger til grund for spørgsmålet selv, eller rettere: fordi gåden ligger i at spørge, eller i at han i det hele taget spørger.

Uanset hvor meget han kæmper med sig selv, kan han ikke finde ro, selv ikke efter at han rent intellektuelt føler sig overbevist om sandheden i de bibelske tekster og den katolske kirkes autoritet. Hverken i sit intellekt eller i sit hjerte finder han kraften til den endelige beslutning om at lade sig omvende til kristendommen. Men noget forandrer sig dog, da en landsmand ved navn Ponticianus fortæller ham om de omvendelser, som for to af dennes medrejsende skyldtes, at de i en landlig hytte fandt en bog, der skildrede den hellige Antonius' åbenbaring og omvendelse: "Du, herre, tog under hans fortælling og drejede mig omkring. Du trak mig frem bag min egen ryg, hvor jeg havde stillet mig, så længe jeg ikke ville se mig selv. $\mathrm{Nu}$ stillede du mig ansigt til ansigt med mig selv, så jeg kunne se, hvor hæslig jeg var, forkrøblet og snavset, fuld af pletter og sår” (8.7.16).

Igennem Ponticianus' fortælling foranlediges Augustin af Gud til at se sig selv som i et spejl, der stiller ham ansigt til ansigt med sin egen ringhed. Mens menneskesjælen hinsides skal stå ansigt til ansigt med skaberen, sådan som det lyder hos Paulus, må den på denne verdens betingelser nøjes med at stå ansigt til ansigt med sig selv i endelighedens spejl. Augustin erkender da også sin egen slethed, men skammer sig. Han forstiller sig, fortrænger og glemmer det, han ikke vil kendes ved i forhold til sig selv (jf. sed dissimulabam; et connivivebam, et obliviscebar, ibid.). At han således i kraft af vidnesbyrdet om andres omvendelse indser, hvad det er, han ikke selv formår, fører i første omgang til, at han må skjule sig for sig selv. Først da han grædefærdig og udmattet af sin egen kvalfulde ubeslutsomhed kaster sig

9. Formuleringen stammer fra Spinoza, der imidlertid har en panteistisk ontologi i tankerne, og han trækker dermed på et naturbegreb, der er ukendt for Augustin. Formuleringen anvendes i mange forskellige sammenhænge, og vi finder den også hos Wittgenstein, der dermed vil sige, at hvor verden udgør totaliteten af kendsgerninger, får livet først mening gennem evighedens synsvinkel. For Augustin er verden Guds skabning og som sådan forskellig fra Gud, hvilket forekommer sammenligneligt med Wittgensteins henvisning til, at Gud viser hen til noget uudsigeligt højere end summen af kendsgerninger, Tractatus Logico-Philosophicus (København: Gyldendal 1963), 6.432; 4321. Ikke desto mindre erkender Augustin, da han taler til sin egen omvendte sjæl i bog 10, Gud som livet i livet selv: Deus autem tuus etiam tibi vite vita est, 10.6.10. 
ned foran et figentræ og giver tårerne frit løb, kommer noget andet til ham. Han hører en barnestemme, der fra nabohuset syngende gentager ordene "tag og læs, tag og læs" (tolle lege, tolle lege, 8.12.20).

Denne begivenhed er med rette en af de mest berømte og omtalte steder i Bekendelser. Den udgør et højdepunkt i det narrative forløb og er samtidig et vendepunkt i Augustins liv. Den spændingstilstand, der omtales fra begyndelsen som hjertets uro, og som hele tiden mærkes gennem skildringen af de virile, men også rastløse ungdomsår, når en ubærlig grænse i bog 8 , indtil et barns ord forløser den. Augustin foranlediges til at tolke barnestemmens ord som en guddommelig befaling, hvorfor han fattet går til sin bopæl og slår op i Paulus' breve, der allerede ligger fremme. ${ }^{10}$ Det tilfældige opslag lyder: "Ikke i svir og drik, ikke i utugt og løsagtighed, ikke i kiv og misundelse; men ifør Jer herren Jesus Kristus, og plej ikke kødet, så begæringer vækkes" (Rom 13,13-14). ${ }^{11}$ Næppe har Augustin læst disse ord, før et "vishedens lys" (luce securitatis) strømmer ind i hans hjerte og fortrænger "al tvivlens mørke" (omnes dubitationis tenebre, 8.12.29). Augustin er ikke i tvivl om, at disse ord er møntet på netop ham. Blokeringen for hans omvendelse bestod indtil det sidste i præcis den hang til kødelig tilfredsstillelse, som teksten anholder. Augustin ser sig selv som tiltalt direkte af Gud gennem apostlens ord. ${ }^{12}$

Når Augustin nu ser sig selv i tekstens spejl, ser han sig selv i noget andet, i en kontekst, der ikke umiddelbart angår ham, men som han pludselig selv indgår i. Ligesom Gud er uden for tiden, flyttes Augustin hen til et sted uden for sig selv, hvorved han endelig når frem til sig selv i Gud. Augustin omvendes i ordets egentlige forstand. Han vendes om og ser sig selv som et nyt (eller fornyet) selv, fordi han ser det $\mathrm{i}$ lyset af Gud. Det, der tidligere var anstødsstenen set ud fra hans

10. Skt. Antonius' opslag i Bibelen, Matt 19,21, som førte til hans omvendelse, omtales som parallel, 8.12.29, og understreger det divinatoriske aspekt ved omvendelsen, som forlener den med guddommelig autoritet.

11. Non in comessationibus et ebrietatibus, non in cubilibus et impudicitiis, non in contentione et amulatione; sed induite Dominum Jesum Christum, et carnis providentiam ne feceritis in concupiscentiis.

12. Der kan her henvises til den amerikanske religionsfilosof, Nicholas Wolterstorff, Divine Discourse (Cambridge: Cambridge University Press 1995), 51-54, hvis begreb om 'appropriated discourse', betegner det forhold, at en given tekst aktuelt kan virke som middel for (oplevelsen af) en direkte henvendelse fra Gud. Wolterstorff redegør endvidere for, hvorfor teksten må tilhøre en sammenhæng, der i overordnet forstand 'tæller som' et medium for Guds tale $(1995,54)$. Wolterstorff indleder faktisk sine 'philosophical reflections on the claim that God speaks' (bogens undertitel) med et kapitel om Augustins auditive oplevelse, der begrebsligt holdes adskilt fra et mere klassisk åbenbaringsbegreb, der ikke nødvendigvis indebærer forestillingen om en guddommelig taleakt (1995, 8-11; 19 ff). 
nyplatoniske orientering, nemlig forkyndelsen af, at Gud kunne antage et menneskes skikkelse, bliver nu det, der bortvejer hans skepsis. Netop fordi Gud har antaget et menneskes skikkelse, opløses det spørgsmål, han ikke selv formåede at besvare, nemlig spørgsmålet om, hvorvidt sjælen, endsige himmel og jord, kunne rumme Gud? Jesus Kristus er det ord (7.19), logos, som for det ydre øre lyder i tiden, men som for det indre øre, lyder fra selve begyndelsen, den verdensskabelse, hvormed Gud allerede har planlagt sin ankomst i tiden (11.6-8). Med det ord, der på en gang er Gud og det ord, han har sat i stedet for sig selv i forkyndelsen, overvindes kløften mellem det foranderlige og det uforanderlige. Hvordan kommer Gud ind i sjælen? Som ordet gennem det ydre øre, omsat til dets 'evige betydning' for det indre øre (11.6).

\section{Kærligheden}

Som baggrund for Augustins genbrug af den paulinske passus om spejlets gåde, må vi kaste et enkelt blik på konteksten i det første Korinterbrevs kapitel 13. Når Paulus taler om at se i spejlet som det at se $i$ en gåde, taler han $i$ overordnet forstand om kærligheden. Interessant nok bekender han, at selv hvis han talte med engles tunger og ikke havde kærlighed, da var ordene for intet at regne (1 Kor 13,1). Selv hvis han i kraft af troen kunne flytte bjerge og ikke havde kærlighed, da var hans tro for intet at regne (1 Kor 13,2). Selv hvis han gav alt, hvad han ejede til de fattige, ja endog ofrede sit eget liv, og ikke havde kærlighed, da kunne det hele være lige meget. For kun i kraft af en kærlighed, som ikke søger sit eget og som aldrig skal forgå, skal vi erkende, ansigt til ansigt med skaberen, der kender og elsker os fuldt ud. "Så bliver da tro, håb og kærlighed, disse tre; men størst af dem er kærligheden” (1 Kor 13,13). Spejlets gåde er kærlighedens gåde.

For den unge Augustin er kærlighed og lyst tæt sammenslyngede. Hans levnedsskildring giver et indtryk af, at han uden større vanskelighed formåede at finde tilfredsstillelse for sine mange lyster, herunder en udtalt erotisk appetit. Han lod sig forføre af "forskellige lidenskaber" (variis cupiditatibus, 4.1) og var selv, som en begavet retoriker, i sine drifters vold, en forfører, både på det verbale og det erotiske plan. Alligevel synes der i hele denne livsførelse at indsnige sig en mangel, som ikke kun hidrører fra det tilbageblik, hvormed han i skrivende stund tager afstand fra sine tidligere laster. Hans succes som romersk lærer i retorik smigrede hans forfængelighed, men bragte alligevel ikke hans hjerte den ro, det søgte. Hans erotiske begær 
blev tilfredsstillet $\mathrm{i}$ et "lidenskabeligt kærlighedsforhold" (libidinosi amoris, 4.2.3), men bragte ham alligevel ikke den attråede ro. Mest tilspidset genkalder Augustin sig sin ungdommelige værens mangel gennem tabet af en nær ven, der en tid var ham kærere end alt andet (4.4.7). Smerten over vennens bortgang formørkede hans hjerte, og hans blik tog farve af døden.

"Min fødeby var mig en pine og mit fædrene hus en ulykke, og alt, hvad jeg havde delt med ham, blev uden ham forvandlet til umådelig lidelse" [...] "Kun gråden var mig sød. Den blev nu min sjæls glæde i stedet for den ven, jeg mistede" (4.4.9). Den unge Augustin begræd sit eget afsavn, og kun de tårer, der for en stund vedligeholdt kærlighedens patos, kunne bringe ham lindring. Alt andet havde mistet sin tiltrækning, da han ikke længere kunne dele det med den ven, i hvem han havde deponeret sit halve hjerte (4.6). Overraskende nok har Augustin netop i den forrige bog bekendt, at han, da han senere i sit 19 'nde år kom til storbyen Karthago - "denne heksekedel” (sartago), der sydede og boblede omkring ham af "forbudte elskovshistorier" (flagitiosorum amorum, 3.1) - endnu aldrig havde elsket nogen, men blot elsket elskoven (jf. amans amare). I sin afdøde ven troede Augustin for en stund at have fundet kærligheden, men indså, at han alligevel ikke havde fundet den. Eller rettere: han elskede, men hans kærlighed var ufuldkommen, for han elskede den anden for sin egen skyld. Deri lå hans sorg og hans vrede mod Gud i forhold til det tab, han havde lidt. Men deri stak også sentimentaliteten sin brod, den sentimentalitet, der ikke følger af kærligheden til et andet menneske, men derimod af kærligheden til kærligheden, forelskelsen i forelskelsen selv, den sentimentalitet, der netop lader sig trøste af tårer. $\mathrm{Og}$ som Kierkegaard skriver “....at den Hengivenhed, med hvilken den Elskende giver sig hen til denne Eneste, ja holder ham fast, at det er Selvkjerlighed, det seer blot Christendommen". ${ }^{13}$

Således ser også den omvendte Augustin tilbage og fælder sin dom. I fødebyen Thagaste havde han kun øje for sin egen sønderrevne sjæl. Det var i sidste ende den, han elskede, ja, som han havde forelsket sig i (4.7). Derfor måtte han flygte fra byen, da han mistede sin ven (ibid), for han flygtede i virkeligheden fra sin egen sjæl. ${ }^{14}$ Endeligheden havde forblændet ham. "Ulykkelig var jeg, og ulykkelig er hver en sjæl, som er bundet i venskab til noget dødeligt" (4.6). Heroverfor tager den aldrende Augustin til genmæle: "Salig er den, som elsker dig, elsker sine venner i dig og sine uvenner for din skyld. Kun den

13. Kjerlighedens Gjerninger, SKS, 9 (København: Gads Forlag 2006), II.B, 61.

14. Det er nærliggende her drage en parallel til Kierkegaards begreb om svaghedens fortvivlelse (lagt i munden på Anti-Climacus), Sygdommen til Døden, SKS, 11, (København: Gads Forlag 2006), 135 f. 176 ff. 
alene kan ikke miste nogen af sine kære, som har dem alle kær i ham [Gud], de aldrig skal miste" (4.9). En lignende bestemmelse af kærlighedens bestandighed genlyder hos Kierkegaard, der med henvisning til Paulus' ord om kærligheden som lovens fylde (Rom 13, 10), skriver: "Den verdslige Viisdom mener, at Kjerlighed er et Forhold mellem Menneske og Menneske; Christendommen lærer, at Kjerlighed er et Forhold mellem: Menneske - Gud - Menneske, det er, at Gud er Mellembestemmelsen” (SKS, 9, III.A, 111), “... og hvem er det andet end vor Gud," skriver Augustin, "den Gud som har skabt himlen og jorden og opfylder alt, fordi han har skabt det ved at give det fylde?" (4.9). Kun det menneske er i sidste ende i stand til at vende blikket fra død til liv, som ikke ser verdens fylde gennem forgængelighedens forelskede blik, men gennem loven og skabelsen. "Han [Gud] har nemlig ikke skabt denne verden og så trukket sig tilbage; men af ham og i ham er alt" (4.12). Dermed viger sentimentaliteten og det æstetiskes sanseforførende tiltrækningskraft for noget større. "Det skønne ville jo ikke være noget, hvis det ikke var fra dig. Det bliver til og forgår. Når det opstår, begynder det ligesom at være til, det vokser for at fuldkommes, og når det er fuldkomment, ældes det og dør. Ikke alt bliver gammelt, men alting forgår" (4.10), og når dette forgængelighedens uundgåelige vilkår i det konkrete tilfælde sønderriver sjælen, skyldes det "et usundt begær, fordi den selv ønsker at være til og at finde hvile i det, som den elsker" (ibid). Men sjælen kan ikke finde hvile i den elskede genstand, som den ønsker at spejle sig helt og fuldt $\mathrm{i}$, for dermed vil den i virkeligheden ikke vide af sig selv. Den flygter fra sin egen natur ved at deponere sin sjæl i en anden. "Jeg vendte nemlig ryggen til lyset og ansigtet mod de ting, der var belyst; så mit ansigt, som jeg betragtede dem med, var ikke selv belyst" (4.16)..$^{15}$ Kun for så vidt som denne relation ikke træder ind foran lyset og skygger for det, men selv lader sig oplyse af det, skal den forblive hos Gud (4.11).

Ved denne kærlighed, som ikke søger sit eget og som ikke ophører, skal vi engang ophøre med at erkende stykkevis, og vi skal kende alt, helt og fuldt, ansigt til ansigt med den, der kender os, helt og fuldt. Jesus Kristus var for Augustin vidnesbyrdet om denne kærlighed, el-

15. Augustin taler i denne passage om de frie videnskaber, men forholdet kan uden videre overføres på skaberværket som sådant, og kan på samme måde gælde relationen til et andet menneske. I modsætning til Kierkegaard udgør den kosmologiske relation mellem natur og sjæl en underliggende præmis Bekendelser igennem, hvorfor bl.a. spejlmetaforen bruges om begge dele. Således kan vi f.eks. i bog 13 læse: "Nu ser vi det i skyernes gåde og i himlens spejl og ikke, som det er; for skønt også vi er din søns elskede, er det endnu ikke åbenbaret, hvad vi skal blive". 
ler rettere: han var denne kærlighed selv, helt og fuldt, som det lys, der fortrængte mørket fra menneskenes blik. Også han gik bort, men kun "fra vores øjne, for at vi skulle søge i vores hjerter og finde ham der" (4.12), og således er det ikke længere gennem "kødelighedens slør' (retia carnis) men hinsides, "at vi skal bliv ham lig, thi vi skal se ham, som han er" (similes ei erimus, quoniam videbimus eum sicuti est, 13.15), personficeringen af den evige kærlighed, som ikke søger sit eget.

\section{Moderen (Monika og kirken)}

Der skal ikke megen fantasi til, at udlægge forholdet mellem Augustin og hans moder, Monika, som et eksempel på Freuds 'ødipuskompleks'. Augustin har ikke meget pænt at sige om sin far, som han endda undlader at omtale ved navn indtil de sidste passager i den selvbiografiske del af Bekendelser. Det skal jeg vende tilbage til. Faderen spiller en beskeden, men dog ikke uvæsentlig rolle, i begyndelsen af Bekendelser. Han omtales anonymt som "denne far" (illo pater), der opdager drengens seksuelle modenhed på badeanstalten og som derfor glæder sig til børnebørn, ligesom han fremstilles som den, der nærer uddannelsesmæssige ambitioner på drengens vegne. Monika nærer mest af alt en anden slags forhåbninger til sin søn. Forskellen er, at faderen er udøbt, mens Monika er døbt og en troende kristen. Det er faderen, der med de nødvendige midler leder Augustin ind på de jordiske fortjenesters vej, mens moderen i tålmodig bøn forbereder de himmelske. Bagom denne forskel, der retrospektivt kaster et forståeligt lys over Augustins utvetydige præference for sin moder, lurer også en mere erotisk forskel. Som den retorisk-litterære mester Augustin var, lader han dette fremgå af en seksuelt ladet metaforik, der gælder fuldbyrdelsen af et spirituelt fællesskab mellem moder og søn. Man kan uden videre anvende Freuds begreb om sublimering på dette forhold, men dermed synes der ikke at være vundet meget i forståelsen af, hvad der egentlig er på færde for Augustin. Han omtaler igen og igen kødelige relationer, f.eks. mellem sundhed og sygdom, nærende og næringsfattig føde, overført på forholdet mellem Gud og menneske. Den egentlige sundhed, der ikke angår legemet, men sjælen, kan alene Gud sørge for; den føde, som sjælen hungrer efter, kan legemlig føde ikke mætte, men kun Gud. På samme måde med de erotiske følelser, der, som udtryk for en sand længsel, ikke lader sig tilfredsstille på legemets betingelser, men alene på åbenbaringens. Og endelig gælder den sande avlekraft ikke evnen til at sætte børn i verden, men evnen til at udbrede Guds ord. Som vidnesbyrd tjener Be- 
kendelser netop dette formål; at avle forståelse for Guds ord, ja endog tilskyndelse til omvendelse. ${ }^{16}$

Når Augustin taler om sex, taler han om 'begærets hængedynd', men det forhindrer ham ikke $i$ at tage en seksuel metaforik i anvendelse, når han taler om åndens løftelse. Med den erotiske kærlighed forholder det sig som forskellen mellem det ydre og det indre menneske. ${ }^{17}$ Ser man kun livet på forgængelighedens præmisser, ser man ikke livet i livet. Søger man alene det ydre, finder man aldrig ro, men er hele tiden på jagt efter nye adspredelser. Legemets lyst og jegets forfængelighed tilfredsstilles kun kortvarigt, men hjertets uro sætter sig som en 'sygdom til døden', som en fortvivlelse, der netop består i at holde sig den sandhed fra livet, sjælen samtidig skriger af længsel efter. Det legemlige behov er som den søvnige dovenskab, der făr os til at vende os om på den anden side, når vi egentlig bør stå op. "Straks, lige straks, vent lige et øjeblik!", som Augustin skriver, "Men det 'straks, straks' fik ingen ende, og det lille øjeblik blev langt" (7.5). Han kan ikke tage sig sammen. Han foretrækker at gøre sig det behageligt i sin rastløse lidelse frem for at tage den bitre medicin, som vil kunne helbrede den.

Monika venter i kulissen. Hun bifalder de ægteskabelige planer, som skal sætte en stopper for Augustins illegitime samliv med den kvinde, han elsker, men helst ser hun, at han helt omvender sig til den Gud, der allerede har bygget sit tempel i hende.

Efter Augustins omvendelse i bog 8 ser det ud til at skulle lykkes, og i bog 9 følger da den spirituelle forening mellem mor og søn. Oplevelsen finder sted kort før moderens død. Mor og søn har taget ophold i Ostia forud for den planlagte hjemrejste til Afrika. De står sammen ved et vindue og ser ud i en gårdhave foran huset. De taler kærligt sammen og glemmer tiden (9.10). Emnet er det evige liv, og de drikker med "hjertets mund" (inhiabimus cordis) af "den livets kilde" (fontis vita), som er hos Gud.

Samtalen førte os til, at ingen af de kødelige sansers nydelse, hvor stor den så er, og hvor herligt et jordisk lys den så står i, tåler at sammenlignes eller blot at nævnes sammen med saligheden i det andet liv (illius vitæ). Derpå løftede vi os med glodende begejstring op imod det, som er det

16. Jf. Gillian Clark, Augustine: The Confessions (Bristol: Phoneix Press 2004), 8689, m.h.p. Petrarca og Teresa af Avila.

17. Ligesom Augustin flere gange skelner mellem det indre og det ydre øre, skelner han også mellem det indre og det ydre menneske, hvilket antagelig kan føres tilbage til Paulus, 2 Kor 4,16-18: “...for selvom vort ydre menneske går til grunde, fornyes dog vort indre menneske dag for dag”, en skelnen også Kierkegaard tager op, se Claudia Welz, "Frihed til kærlighed hos Luther og Kierkegaard", Dansk Teologisk Tidsskrift 2 (2009), 99-121 (105-106). 
samme (erigentes nos ardentiore affectu in idipsum) ${ }^{18}$ [...]. Endnu højere steg vi gennem vores indre tanker [...] og vi kom til vores egne sind og gik ud over dem for at nå til den egn, hvis frugtbarhed ikke slipper op, hvor du lader Israel græsse til evig tid på sandhedens eng. Der er livets visdom, den ved hvilken alt bliver til [...]. Mens vi talte sammen og længtes efter visdommen, rørte vi let ved den med et enkelt slag af vores bankende hjerte. Vi sukkede og efterlod åndens førstegrøde, som nu var bundet dér; og vi vendte tilbage til lyden af vores egen mund, hvor ord både har begyndelse og ende. (9.10)

Den åbenbaring, mor og søn her deler, overskrider de kødelige sansers nydelse. Deres oplevelse er inkommensurabel med erotikkens endelige betingelser, men netop ved at afvise sammenligneligheden sammenligner Augustin implicit den kødelige fuldbyrdelse med den åndelige.

I den åndelige forening stiger mor og søn op til deres egne sind og endnu højere til den egn, hvis frugtbarhed aldrig slipper op. Det er denne førstegrøde, de atter må forlade. Den tilhører ikke det liv, de lever som dødelige, men et liv hos Gud, der ikke desto mindre befrugter troen, håbet og - i særdeleshed - kærligheden. Guds kærlighed og kærligheden til Gud er pant på den evige salighed som et håb eller et løfte om engang at kende helt og fuldt. Og endelig: "Kødets uro tier"! (9.10). Mor og søn har fået en forsmag på denne sidste sandhed. De har overskredet det spejl, som deres eget sind udgør for dem selv, og ser i stedet sig selv i lyset af noget andet end sig selv, den evige frugtbarheds eng, Israel, selve Gudsrigets metafor.

Visionen ligner en plotinsk unio mystica, en uudsigelig sammensmeltning med "det ene" (to hen), den rene, forskelsløse væren Vi hører intet om nogen mediator. Tværtimod synes de at høre Guds eget ord. " $[\mathrm{h}]$ verken fra menneskers tunge eller med englestemme (vocem angeli), ${ }^{19}$ ej heller fra tordenskyen eller i gåde og lignelse, men fra ham selv, som vi elsker i alle disse ting”, håber de på at høre sandheden (ibid.), og Gud synes at opfylde deres ønske, om end kun ved et enkelt slag af deres bankende hjerte. Det indre øre lytter med hjertet, og det evige liv smelter sammen med erkendelsens øjeblik (ibid.). Selvfølgelig varer alt dette kun en stund. Med et suk vender de tilbage til den kødelige tilværelses normale tilstand, men Monika bekendtgør dog, at hun ikke har mere at ønske sig af dette liv. På dødslejet fremsætter hun et sidste ønske om ikke at blive begravet i hjemlandet. "Intet er langt fra Gud", siger hun og har dermed frigjort sig

18. Udtrykket ardentiore affectu kan også oversættes med 'løftet stemning' eller 'lidenskabelig sindstilstand'; in idipsum kan også oversættes med 'ind i det selvsamme'.

19. Man kommer uvilkårligt til her at tænke på barnestemmen i bog 8 . 
fra de kulturelle konventioner, der påbyder hende at hvile ved siden af sin ægtefælle.

For Augustin betyder dette, at han anspores til at gentænke hele sit tilhørsforhold til himmel og jord, nemlig den himmelske oprindelse hos Gud og den jordiske tilblivelse ved sine biologiske forældre. Netop dermed får hans livsforløb form, hvilket afspejles i en forskudt relation mellem de jordiske og det himmelske forældrepar, som samtidig relokaliserer de indbyrdes relationer i Guds rige, der gør alle til søskende. Dette fremgår af følgende 'erotiske' og 'familiære' kobling mellem de to første bøger og bog 9 , hvilket samtidig danner ramme om den selvbiografiske del af Bekendelser:

\begin{tabular}{|c|c|}
\hline $\begin{array}{l}\text { 1.13: } \\
\text { Gud, du mit hjertes lys, du brød i } \\
\text { min sjæls mund, du avlekraft dybt i } \\
\text { mit sind. (Dues lumen cordis mei, et } \\
\text { panis oris intus anima mea, et virtus } \\
\text { maritans mentem meam et sinum co- } \\
\text { gitationis mea) }\end{array}$ & $\begin{array}{l}\text { 9.2: } \\
\text { Du havde ramt vores hjerte med din } \\
\text { kærligheds pil, og vi bar på dine ord, } \\
\text { som havde gennemboret vores in- } \\
\text { dre. Dine tjeneres forbilleder, som } \\
\text { du havde forvandlet fra sort til hvidt } \\
\text { og fra død til liv, lå samlet i vores } \\
\text { tankes skød (congesta in sinum cogi- } \\
\text { tationis nostra) }\end{array}$ \\
\hline $\begin{array}{l}\text { 2.3: } \\
\text { Da denne far (illo pater) så mig på } \\
\text { badeanstalten, mens jeg var i puber- } \\
\text { teten, og min krop viste tegn på } \\
\text { ungdommens uro, fortalte han glad } \\
\text { min mor om, hvordan de nu kunne } \\
\text { vente sig børnebørn ... Men i min } \\
\text { mors bryst (pectus) var du allerede } \\
\text { begyndt at bygge dit tempel og hav- } \\
\text { de lagt grund til din hellige bolig } \\
\text { (sancte habitationis tue) }\end{array}$ & $\begin{array}{l}9.13 \\
\text { Lad hende da hvile i fred med sin } \\
\text { mand... } \\
\text { Indgiv du, min herre og min Gud, } \\
\text { indgiv du i dine tjenere, mine brød- } \\
\text { re, dine børn ... at så mange som } \\
\text { læser dette, ved dit alter vil mindes } \\
\text { Monica, din tjenerinde, sammen } \\
\text { med Patricius, hendes tidligere æg- } \\
\text { tefælle, ved hvis kød du har ført mig } \\
\text { ind i dette liv, jeg ved ikke hvordan. } \\
\text { Lad dem fromt og kærligt mindes } \\
\text { dem, som var mine forældre i dette } \\
\text { flygtige lys, men mine søskende ved } \\
\text { dig, fader, i vor moder, den katolske } \\
\text { kirke og mine medborgere i det evi- } \\
\text { ge Jerusalem... } \\
\text { Da vil min moders ønske [om at bli- } \\
\text { ve begravet i Ostia og ikke i Thaga- } \\
\text { ste ved siden af sin mand. Jf. 9.11] } \\
\text { blive rigeligere opfyldt end ved mine } \\
\text { bønner alene. }\end{array}$ \\
\hline
\end{tabular}

Augustin foretager med andre ord en dissociation mellem det jordiske lys, som skinner i forandringens verden, og den evige salighed, som lyser i det andet liv (Guds rige). Dermed associeres den legemli- 
ge kærlighed (såvel i erotisk som i prokreativ forstand) med lyset i denne verden, $\mathrm{i}$ hvilken Monica og Patricius anerkendes som mor og far, mens charitas, den guddommelige nåde og kærlighed, skaber en association til den katolske kirke og Gud selv som det sande eller himmelske forældrepar i forhold til hvilket, Augustin, Monica, Patricius (og alle andre) er børn og derfor hinandens søskende. Samtidig følger med det himmelske forældrepar en ny topografi, den katolske kirke og det forjættede 'evige Jerusalem', som gør dem alle til borgere i samme 'by'. Dermed kan Monica hvile sammen med sin tidligere ægtefælle (quondam ejus conjuge) i Guds stad.

Grafisk vil dette kun anskueliggøres som et forhold mellem Augustin, Monica og Patricius, der igen står i forhold til Gud og kirken, således at en indledende dissociation mellem Augustin og hans far forstærker associationen mellem ham og Gud (som den sande far), ligesom dissociationen mellem den kristne Monica og den ukristne Patricius forstærker associationen mellem Monica og Gud (som hendes sande ægtefælle?). Endelig gør det himmelske forældrepar, Gud som fader og kirken som moder, en forsoning mulig, således at Augustin kan anerkende (og ære) sin kødelige far, og Monica kan hvile ved siden af sin (tidligere) ægtemand.

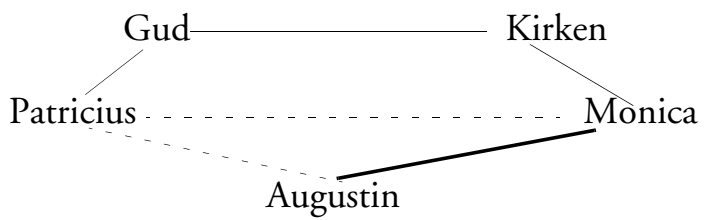

En gennemgående erotisk metaforik løftes således fra en legemlig til en ulegemlig betydningsramme, nemlig fra tiltrækningen mellem det forskellige (den kønslige kærlighed) til saligheden i det samme (mor og søn forenes, forskellen mellem Gud som fader og kirken som moder ophæver den kødelige betydning af en forskel i køn). Gud befrugter sjælen med det sædekorn, som er ordet (logos = Kristus).

Med troen på Gud og tilhørsforholdet til den katolske kirke etableres en spejlingsakse, som løfter mennesket ud af dets eget forhold til sig selv. Tilværelsens gåde er ikke løst, den endelige forløsning må vente, men hjertet har fundet hvile i Gud. "Dette er nemlig Formelen, som beskriver Selvets Tilstand, naar Fortvivlelsen ganske er udryddet: i at forholde sig til sig selv, og i at ville være sig selv grunder Selvet gjennemsigtigt i den Magt, som satte det" (Søren Kierkegaard, SKS, 11, A.A., 130). Ser vi bort fra, at kirken på ingen måde udgør 
en uantastelig autoritet hos Kierkegaard (snarere tværtimod), kunne disse ord meget vel møntes på den ro, Augustin finder i Gudsforholdet.

\section{Mellemstadie}

I bog 10 gør Augustin regnskabet op. Han refererer ikke længere til sit liv forud for omvendelsen, men til det liv, han nu lever som kristen. Den nye tilstand fritager ham imidlertid ikke fra tilbagefald i synden. Med til livet hører daglige fristelser (10.37), og selvom han, i det mindste efter eget vidende, afholder sig fra glæder, der vender ham bort fra Gud, eftersom fristelsens billeder ikke længere har nogen magt over ham i vågen tilstand, så får de ham i drømme til at føle nydelse og til at give efter for noget, som ligner virkelighed (10.29). "Så stor magt har de forføreriske billeder over min sjæl og mit kød, at de falske syner får mig til at gøre i søvne, hvad de ikke formår i vågen tilstand" (ibid.). Selvom omvendelsens lys har fortrængt det kødelige begær fra Augustins bevidste vilje, vender det tilbage som en tyv om natten og berøver ham visheden om helt og fuldt at være Gud til behag.

Som omvendt kristen kan Augustin imidlertid, nu hvor beruselsen fra den umiddelbare Gudsnærhed har fortaget sig, og anfægtelsens stunder stadig har det med at melde sig, læne sig op ad den inkarnerede Guds søn, som har taget alle menneskers synd på sig. Men ophøre med at spørge kan han ikke. Faktisk er det gentagelsen af bekendelsernes overordnede spørgsmål, angivet som bøn, der indleder og indrammer bog 10: "Lad mig kende dig, du som kender mig, lad mig kende dig, ligesom jeg jo selv er kendt". Denne implicit paulinske henvisning følges op af en mere udfoldet reference i 5 te kapitel: "Sandelig, nu ser vi i et spejl, i en gåde, endnu ikke ansigt til ansigt; derfor er jeg nu mere nærværende for mig selv end for dig, så længe min udlændighed varer" (10.5). Augustin er stadig konfronteret med sig selv i sin spørgen ind til Gud; det ligger i hans jordiske, dødelige og legemlige konstitutions betingelser, men forskellen er, at han nu indser det i kraft af noget andet. "Under dit blik er jeg blevet til et spørgsmål for mig selv - det er det, jeg fejler" (10.33). Det er i kraft af noget andet end ham selv, at han nu ser sig selv i spejlet som et spørgsmål, han stiller til sin egen eksistens. Dette er på én gang gåden og gådens løsning. Svaret er i en vis forstand, at spørgsmålet overhovedet stilles. Gåden forbliver en gåde, men med udgangspunkt i noget andet, med udgangspunkt i 'en magt, som Selvet gennemsigtigt grunder i'. 
Kierkegaard formulerer i en af sine opbyggelige taler et lignende spejlbillede, hvor selvet idet, det ser sig selv, samtidig ser ind i den modsigelse, som Kristus er.

[S]ee, idet man seer, seer man som i et Speil, man kommer til at see sig selv, eller han, der er modsigelsens Tegn, seer En lige ind i Hjertet, medens man stirrer ind i Modsigelsen. En Modsigelse stillet lige over for et Menneske [...] et et Speil; idet han dømmer, maa det blive åbenbart, hvad der bor i ham. Det er en Gaade; men idet han gjetter, bliver det aabenbart, hvad der boer i ham, ved hvorledes han gjetter. (Søren Kierkegaard, SKS, 11, A.A., 131)

For Augustin består der også 'en modsigelse' ved Kristus, som både er Gud og menneske, mens han selv, som skabning, står i absolut modsætning til skaberen. ${ }^{20} \mathrm{Og}$ dog forsøger Augustin samtidig - og mest udfoldet i De Trinitate - at forholde sig til treenighedens natur på troens timelige betingelser (næsten som $\mathrm{i}$ en thomistisk analogia en$t i s$ ), og han ser han således treenigheden afspejlet i sjælens tredobbelte natur som memoria, intelligentia og voluntas. ${ }^{21}$ Men ligesom selvet forbliver en gåde for det levende menneske, således også treenigheden: "Se, i en gåde viser Treenigheden sig for mig", som det lyder i Bekendelser, hvorefter den kosmologiske forbindelse til himmel og jord samt til Kristus straks følger, eftersom treenigheden "er dig, min Gud; for du, fader, skabte himlen og jorden i begyndelsen til vores visdom, som er din egen visdom, født af dig, lig med dig og lige evig med dig, det vil sige i din søn” (13.5).

Således forsøger Augustin platonisk og utålmodigt at overskride dødelighedens og timelighedens grænser. Men Gudsbekendelsen slår hele tiden om i et spørgsmål: "Hvad er det da jeg elsker, når jeg elsker dig?” Selv svarer han, at det ikke er noget enkelt fænomen, der er genstand for hans kærlighed, men det sarlige i alt, som stammer fra

20. For Augustin er Kristus dog, som ovenfor omtalt, først og fremmest mediator mellem menneske og Gud, og selvom Augustin foregriber to-natur-læren ved at anerkende såvel guddommeligheden som menneskeligheden i Kristus, finder vi ikke den humanistiske klangbund hos Augustin, der hos Kierkegaard gør at Kristus i egentlig forstand kan fremstå som en modsigelse. Det er som skabning, at Augustin ser sig selv i absolut modsætning til Gud i hvis billede, han ikke desto mindre er skabt, og deri består spejlets gåde bl.a., mens det - med Hegel som mellemstation - forholder sig mere dialektisk hos Kierkegaard.

21. Se Augustin, De Trin., Confessionum libri tredecium i Patrologia latina vol 32, red., J.P. Migne (Turnhaut: Brepols 1969-1987), III; XV 23, 43, hvor voluntas står parallelt med amor; sammenlign ligeledes IX 4, 4, hvor den sjælelige treenighed omtales som mens-notitia-amor med Conf. 13.11.12: esse, nosse, velle. Se endvidere Karsten Friis Johansen, Den Europaiske Filosofis Historie. Antikken (Viborg: Nyt Nordisk Forlag Arnold Busk 1994), 768. 
Gud, det sanselige omsat fra det ydre til det indre menneske. Således er det ikke længere "de lemmer, som kødet så gerne favner", Augustin attrår, men Gud som "omfavnelsen i mit indre menneske", og "dét favntag vedvarer, som ingen tilfredsstillelse løsriver mig fra. Det er dette, jeg elsker, når jeg elsker min Gud" (10.6).

Augustin taler endnu som platoniker, men selvfølgelig som en kristen platoniker, som en der higer efter at forstå under troens fortegn. ${ }^{22}$ Augustin spørger, og svaret gives i kraft af det lys, der vender øjet fra dødens skygge, til "livet i livet selv" (vito vita, 10.6). Gud viser sig i det skabte under evighedens synsvinkel, sub specie aeternitatis. Når Gud på samme måde lader Augustin se sig selv i spejlet som en gåde, viser dette selv ikke tilbage til et selvberoende selv, men til det selv i selvet selv, der, skabt i Guds billede, viser tilbage til Gud.

\section{Begyndelse og slutning}

Af "kærlighed til Guds kærlighed" (11.1) helliger Augustin sig i bog $11 \mathrm{og}$ i resten af Bekendelser en eksegese af de første 35 linjer af Genesis. Det handler om "begyndelsen" (principium), ikke en begyndelse i tid, men om altings begyndelse, også tidens. Gud har skabt verden og tiden på én gang (concreatio), og alle spørgsmål til, hvorledes en begyndelse overhovedet giver mening for en skaber, der selv befinder sig uden for tiden, afvises som absurde (11.12), fordi de stilles på tidens, og dermed på den begrænsede menneskeforstands præmisser. Begyndelsen er ordet (Johs1,1; 3,29; 8,25), og derfor er begyndelsen både verdens begyndelse og Kristus, Guds fornyende tilstedeværelse i verden. Begyndelsen er et paradoks eller en gåde, på én gang en dennesidig meddelelse og en stemme udefra. "Disse ord fra dig, som lød til en vis tid, blev meddelt gennem det ydre øre til det forstandige sind, hvis indre øre lytter efter dit evige ord" (11.6). Såvel den gammeltestamentlige som den nytestamentlige forkyndelse, nemlig skabelsesberetningen på den ene side og kristologien på den anden, udgør en spejlingsakse mellem Gud og menneske: Evigheden meddeler sig timeligt gennem menneskets ydre øre, for at det indre øre kan høre det evige ord, og "det er selve dit ord, der også er begyndelsen, fordi det taler til os" (11.8).

I sin udlægning af de første linjer i Genesis, bekender Augustin foreløbig ved 'himlens himmel' at forstå "en begrebsmæssig himmel,

22. Jf. "ecce pietas et sapienta", 5.5.8, sml. Sal 8,8; 1 Johs 2,15, reformuleret hos Anselm som "credo ut intelligam", Proslogion. Guds Virkelighed (Frederica:Lohse 1982), kap. 1. 
hvor det at erkende betyder at kende på én gang, ikke stykkevis, ikke i en gåde, i et spejl, men fuldt ud og klart, ansigt til ansigt, altså ikke at kende snart det ene og snart det andet, men som sagt på én gang uden nogen tidsforskel.” (11.13)

Igen skinner Augustins platoniske tænkemåde tydeligt igennem, men mere interessant er det, at det atter er den paulinske spejlmetafor, der tages i anvendelse, nu overført fra den individuelle sjæl til verden som sådan, altså fra mikrokosmos til makrokosmos. Samtidig føjer begyndelse og slutning sig sammen i en cirkel uden for tiden. Ved livets ophør, ansigt til ansigt med skaberen, skal vi erkende alting fuldt ud og klart, verdens begyndelse og sjælens natur. Guds plan med det enkelte menneskes livsforløb og verdens tilblivelse står i forbindelse med hinanden. Der er i virkeligheden ingen forskel, i Guds stad er alle søskende, og det er ikke længere den menneskelige tilværelse, men livet i livet selv, ikke denne verdens himmel og jord, men himlens himmel og jordens jord, der afsløres for os som den sammenhæng, i hvilket gåden endelig opløser sig. Da skal vi skue i stedet for blot at tro, som Augustin formulerer det (13.13; De Trin. 2) i forlængelse af Paulus (2 Kor 5,7). Vi skal ikke længere nøjes med at lytte med det ydre øre, men vi skal høre ordet, som det er, hos Gud selv, som Gud selv. ${ }^{23}$ Med Augustins egne ord:

Altså: før alle ting blev der skabt en visdom, som er skabt, det fornuftige og forstandsmæssige sind i din kyske stad, vor moder, som er oventil og fri, og som er evig i himlene - ja, i hvilke andre himle end de himlenes himle, som priser dig? Og det er det samme, som den himlens himmel, der er herrens (12.15).

En ikke helt klar forbindelse knyttes mellem en platonisk og en paulinsk tankegang, mellem menneskets fornuftsforudsætninger og kirken som det Guds hus, de må udfolde sig inden for, men vigtigst af alt peger Augustin på den udlændighed, hvormed han som dødeligt menneske længes efter "Jerusalem, mit fædreland, Jerusalem, min moder" og efter Gud som "dets hersker, dets oplyser, fader, værge, brudgom, dets kyske og stærke fryd og dets grundfæstede glæde" (12.16). Bort fra livets adspredelse og forvrængning (jf. non avetar) vil Augustin vende sig "ind til dets fred hos min elskede moder, hvor min ands forstegrøde er" (sunt primitic spiritus mei, 12.16.23, min understregning). Den sande begyndelse finder Augustin således hos sin

23. Som Jørgen Pedersen fint formulerer det i sin indledning til tekstsamlingen i serien De Store Tankere: Augustin (Viborg: Rosinante 2000), 35: "Først når Guds egen uskabte visdom bliver vor tankes spejl, opfyldes forjættelsens ord, at "lys i dit lys skal vi skue"”. 
moder i himlen, det forjættede Jerusalem, der dog også implicit synes at afspejle sig i den biologiske moder, i hvis bryst Gud byggede sit tempel (2.3, se ovenfor).

I den himmelske topografi, der samtidig er begyndelse og ende uden for tiden, den tid, der i øvrigt er en funktion af den menneskelige bevidsthed i dens jordiske begrænsning (jf. den berømte tidsanalyse i bog 11.14-28), ${ }^{24}$ sammenføjes alle brud; dødelighedens sår heles, gåden vil finde sin løsning.

Og det urolige hjerte finder fred. Hen imod tekstens slutning formulerer Augustin denne tilstand som en bøn: "Herre, Gud, giv os freden, thi alt har du gjort for os - hvilens fred, sabbattens fred, freden uden aften! Hele denne skønne ordning af de såre gode ting skal forgå, når hver ting har nået sit mål (peractis); for med dem blev det morgen, og det blev aften" (13.35). Således indbefatter skabelsen det skabtes ophør, men ikke ophøret af den hvile, hvormed Gud markerer fuldbyrdelsen af sit eget værk. Det er denne hvile, Augustin på alles vegne beder om at få del $\mathrm{i}$, og som $\mathrm{i}$ en vis forstand allerede synes realiseret gennem den jordiske sabbat, nemlig i kraft af den implikation, der ligger i henvisningen til dens himmelske spejlbillede.

Skabelsen peger ud over skabelsen selv. I begyndelsen var slutningen indskrevet som ordet om himlens himmel. Verdens skabelse afspejler sig i hjertets uro for det menneske, der forsøger at forme sit liv og forstå dets vilkår. Med verdens og tidens skabelse følger også ufuldkommenhed og længsel. Men alt er såre godt, en skøn ordning af gode ting, for alt hvad Gud har skabt er godt, og hvis længslen vender sig fra det attråedes forgængelighed til dets fylde i skabelsen, kan intet mistes. Således ser vi os selv og verden i det forgængeliges spejl som en gåde, indtil vi ser dette genskin som et spejl for noget andet, en sammenhæng, vi ikke kan tilskrive os selv eller det forgængeliges natur som sådan.

\section{Konklusion}

Jeg har i denne artikel fulgt en bestemt vej gennem Bekendelser ansporet af den paulinske metaforik omkring spejlets gåde, der på den

24. Af de mange temaer i Bekendelser, som ikke berøres i denne artikel, udgør tidsanalysen formentlig et af de interessanteste. Jeg skal blot henvise til K.E. Løgstrups skabelsesteologiske (jf. Skabelse og Tilintetgørelse (København: Gyldendal 1976), 11-17, og til Trond Berg Eriksens idehistoriske udlægning heraf (jf. Augustin. Det urolige hjerte (Oslo: Universitetsforlaget 2002), 189-192; endvidere Paul Ricoeurs mere hermeneutisk-filosofisk udfoldede analyse i Temps et récit, I (Paris: Éditions du Seuil 1983), 21-65. 
ene side viser hen til den menneskelige erkendelses begrænsning og på den anden side til en eskatologisk forventning om erkendelsens fuldbyrdelse. Helt afgørende er det, at meningshorisonten for erkendelsens stræben ikke i sidste ende er givet med en nyplatonisk skuen, theoria, men derimod med Guds altoverskridende kærlighed, charitas. Spejlets gåde er ikke i sidste ende et teoretisk anliggende, men rejser et spørgsmål, som kun kærligheden, charitas, kan besvare. Det er i kraft af denne kærlighed ved Gud - og ikke ved mennesker alene -, at de menneskelige relationer som f.eks. mellem Augustin, hans moder og hans fader, forsones, og forskydes til et søskendeforhold, der bag om denne verdens tid og sted sammenføjes i den helhed, som endnu ikke lader sig skue.

Uanset hvor vidt denne forsoningstanke lader sig drive hos Augustin selv, er den til stede som et spor, der efter hans eget udsagn er unddraget en sidste videns horisont. På samme måde holder også spejlmetaforen sit udsagn åbent, hvilket jeg har udnyttet i forhold til de punktnedslag hos Kierkegaard, hvor lignende refleksioner synes at gøre sig gældende. Denne perspektivering sigter ikke så meget på Augustin eller Kierkegaard selv som på den spørgehorisont, vi deler med dem begge i kraft af deres tekster. De udgør så at sige et spejl, hvori vi fortsat bliver til spørgsmål for os selv. 